\title{
ISOLAMENTO DE LEVEDURAS PROVENIENTES DA POLPA DE SIRIGUELA (SPONDIAS PURPUREA) E PURIFICAÇÃO E ANÁLISE DOS COMPOSTOS GERADOS DURANTE O PROCESSO FERMENTATIVO
}

\author{
$\underline{\text { Joelma Oliveira Souza }}{ }^{1 ;}$ José Ailton Conceição Bispo² \\ 1. Bolsista PIBIC/FAPESB, Graduando em Engenharia de Alimentos, Universidade Estadual de Feira de Santana, e- \\ mail: joelmasouzatst@gmail.com \\ 2. Orientador, Departamento de Tecnologia, Universidade Estadual de Feira de Santana, e-mail: \\ ailton_bispo@hotmail.com
}

PALAVRAS-CHAVE: Fermentação, Isolamento, Modelo de Transição.

\section{INTRODUÇÃO}

A realização de melhorias no desenvolvimento de cervejas e vinhos pelo processo descontínuo utilizando como adjunto frutas do semiárido baiano vêm sendo avaliada há alguns anos com vistas à descoberta de novos produtos e processos. Desde o desenvolvimento de modelos computacionais em ambiente MatLab destinados à modelagem e otimização de processos biotecnológicos de inativação viral, secagem e cinética enzimática (Bispo et al., 2012. 2013a, 2014, 2015), nosso grupo tem voltado a atenção aos processos fermentativos, visto que, uma das mais importantes linhas de investigação cervejeira da região nordeste encontra-se hoje no NÚCLEO DE INOVAÇÃO EM TECNOLOGIAS DE FERMENTAÇÃO da Universidade Estadual de Feira de Santana (UEFS-Bahia). Neste contexto, a presente proposta visa obter condições para compor um setor de modelagem matemático-estatístico capaz de aperfeiçoar as condições de produção e ao mesmo tempo diversificar a gama de produtos fermentados provenientes de frutos climatéricos das regiões norte e nordeste. $\mathrm{O}$ intuito desta pesquisa foi, portanto, a geração de novas patentes de produtos e processos aliadas à geração e registro de softwares de caracterização e controle. Neste contexto, a presente pesquisa objetivou-se obter o isolamento e purificação de leveduras presentes em frutos climatérios, neste caso, foram purificadas e testadas do ponto de vista fermentativo as leveduras presentes na polpa de Siriguela (Spondias purpurea).

\section{METODOLOGIA}

\section{1- Obtenção e Crescimento das leveduras}

As leveduras foram obtidas inicialmente do próprio mosto de siriguela por meio de aeração na presença de nutrientes a base de íons, compostos nitrogenados e com controle do Brix durante 4 semanas.

\section{2-Centrifugação e Liofilização das leveduras}

As leveduras obtidas durante o processo de crescimento foram então centrifugadas a $6000 \mathrm{rpm}$ e uma vez descartado o sobrenadante as mesmas foram liofilizadas durante 8 horas para remoção da água livre para posterior armazenamento em freezer. Embora não fizesse parte do plano de trabalho, este liofilizador foi construído pelo próprio grupo.

\section{3- Análises da Atividade Fermentativa}


$\mathrm{O}$ andamento do processo fermentativo foi monitorado no decorrer do tempo em relação à concentração inicial de inóculo, por meio da produção de etanol determinada através de densímetro digital, grau de fermentação e por produção de dióxido de carbono. A concentração inicial de açúcares dissolvidos será de 8, 12, 14, 18,22 e $26^{\circ}$ Brix para uma variação no inóculo inicial de 5, 10, 15, 25, 30 e 50 \% v/v. Todos os reagentes utilizados foram da grade analítica.

\section{RESULTADOS E/OU DISCUSSÃO}

As leveduras passaram por um processo de crescimento, envolvendo a presença de nutrientes e contando com uma aeração constante com ar filtrado por meio de filtros Hepa. Em seguida, foram centrifugadas e liofilizadas para isolar a cepa de levedura garantindo que essa cepa pudesse ser aplicada para uma fermentação comparativa em relação a outras leveduras. Depois da fermentação, verificou-se a capacidade de produção de etanol por cada cepa de levedura.

Os resultados obtidos experimentalmente no processo fermentativo encontramse demonstrados nos gráficos 1,2 e 3.

\section{Gráfico 1: Relação do ${ }^{\circ}$ Brix x Tempo (h)}

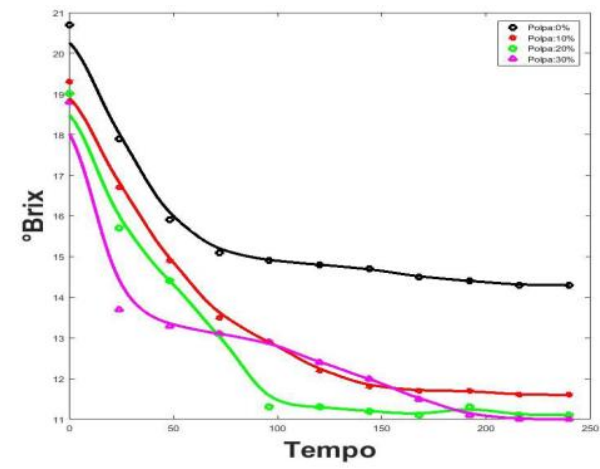

Neste gráfico podemos observar através dos dados experimentais e dos pontos traçados, nota-se que com o aumento do Grau Brix consequentemente tem-se uma redução do tempo de fermentação, isso mostra que as leveduras crescem mais nos primeiros dias do que no final, em que nesses períodos diminuem a velocidade de multiplicação, independente da concentração da polpa. Além do que, apresentarem faixas constantes em cada concentração.

Gráfico 2: Relação da Célula/mL x Tempo (h)

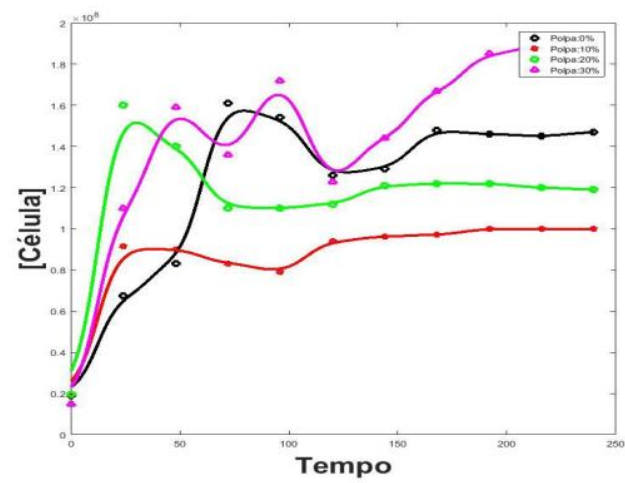


As curvas do gráfico 2 permitem ver mais claramente o comportamento do crescimento das leveduras nas diferentes concentrações. Nota-se que a fase lag é praticamente inexistente e que o mosto com $10 \%$ apresentou baixo crescimento celular.

\section{Gráfico 3: Relação do Etanol (\%) x Tempo (h)}

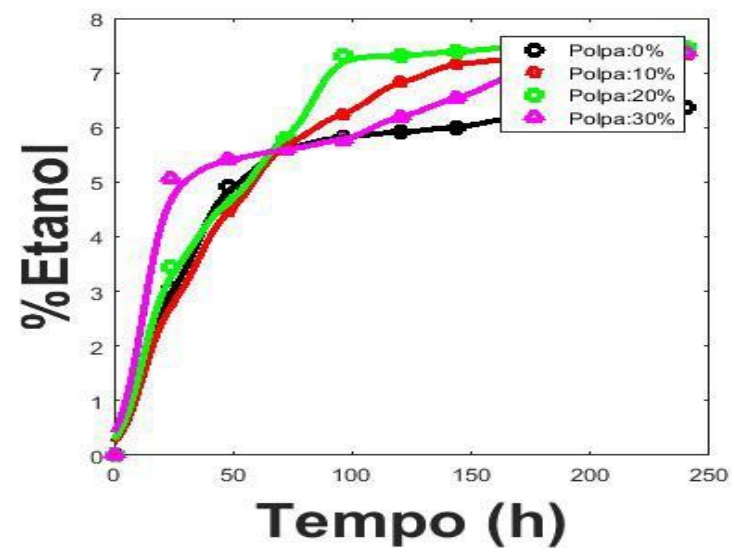

Este gráfico apresenta o resultado da produção de etanol (\%), demonstrando o andamento do processo fermentativo monitorado no decorrer do tempo em relação à concentração inicial de inoculo. A produção de etanol pelas leveduras foi maior quando se utilizou concentração de inoculo de $20 \%$, alcançando $7,47 \%$ de etanol após 168 horas do processo fermentativo, mantendo-se praticamente constante até o final do mesmo. Observando-se maior produção de etanol nesta concentração, seguida pelas de 30 e $10 \%$ de inoculo respectivamente. Sendo clara a menor produção na concentração de $0 \%$. Desta forma, a produtividade aumentou a medida que se utilizou um mosto com maior concentração inicial de inoculo, exercendo influencia positiva na fermentação.

\section{CONSIDERAÇÕES FINAIS}

Observa-se dos resultados experimentais que o processo fermentativo produziu bebidas fermentadas com teor alcoólico, aroma e coloração adequada para geração de produtos com grande potencial de comercialização. Das análises computacionais dos dados experimentais verifica- se ainda um grande capacidade do processo de modelagem de em auxiliar na otimização desses processos tanto em processos contínuos como em batelada ou batelada alimentada. Devido ao baixo custo energético desses processos, os produtos obtidos podem servir como base para patentes de processos bem como para projetos de extensão que visem o desenvolvimento de novos produtos e agregação de valor a frutas coletadas por comunidades nordestinas, auxiliando assim, na geração de renda e no desenvolvimento de cooperativas comunitárias especializadas nesse tipo de bebidas fermentadas com frutas típicas da região.

\section{REFERÊNCIAS}

Bispo, J. A. C., Bonafe, C. F. S., Koblitz, M. G. B., Silva, C. G. S., \& Souza, A. R. (2013a). Substrate and enzyme concentration dependence of the Henri-MichaelisMenten model probed by numerical simulation. Journal of Mathematical Chemistry, 51(1), 144-152. 
Bispo, J. A. C. et al. (2014). Applying structural transition theory to describe enzyme kinetics in heterogeneous systems. J. Mathematical Chemistry.

Bispo et al. (2015). A comparison of drying kinetics based on the degree of hydration and moisture ratio. LWT Food Science and Technology.

Bispo et al. (2014). Optimizing Drying Processes Using a structural Transition Model and Entropy Change Maximization. Drying Technology

Bispo, J. A. C., Silva, C. M. R., Bonafe, C. F. S., \& Assis, D. J. (2013b). Modeling drying isotherms using a structure transition model. Drying Technology, in press.

Bispo, J. A. C., Bonafe, C. F. S., Joekes, I., Martinez, E. A., Carvalho, G. B. M., \& Norberto, D. R. (2012). Entropy and volume change of dissociation in tobacco mosaic virus probed by high pressure. Journal of Physical Chemistry B, 166(51), 1481714828.

Bispo, J. A. C., Bonafe, C. F. S., de Souza, V. B., Silva, J. B. A., \& Carvalho, G. B. M. (2011). Extending the kinetic solution of the classic Michaelis-Menten model of enzyme action. Journal of Mathematical Chemistry, 49(9), 1976-1995.

CARVAlho, G. B. M., ROSSI, A. A., AlmeIDA E SILVA, J. B. Elementos Biotecnológicos Fundamentais no Processo Cervejeiro: $2^{\circ}$ Parte - A Fermentação. Revista Analytica, n 26, p 46-54, 2007. 